\title{
$\begin{array}{r}\text { WAGENINGEN } \\ \text { UNIVERSITY \& RESEARCH } \\ \hline\end{array}$
}

\author{
The RIO approach: Design and anchoring of sustainable animal husbandry \\ systems \\ Elzen, B., \& Bos, B.
}

This is a "Post-Print" accepted manuscript, which has been published in "Technological Forecasting and Social Change"

This version is distributed under a non-commercial no derivatives Creative Commons

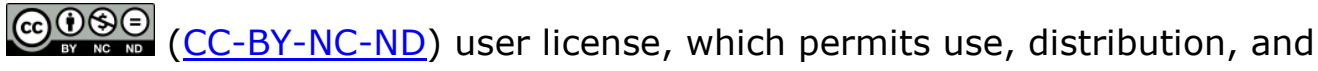
reproduction in any medium, provided the original work is properly cited and not used for commercial purposes. Further, the restriction applies that if you remix, transform, or build upon the material, you may not distribute the modified material.

Please cite this publication as follows:

Elzen, B., \& Bos, B. (2019). The RIO approach: Design and anchoring of sustainable animal husbandry systems. Technological Forecasting and Social Change, 145, 141152. https://doi.org/10.1016/j.techfore.2016.05.023 


\section{The RIO approach: Design and anchoring of sustainable animal husbandry systems}

Boelie Elzen ${ }^{\mathrm{a}, 1}$ and Bram Bos ${ }^{\mathrm{b}}$

\section{${ }^{\mathrm{a}}$ Corresponding author}

Wageningen UR Livestock Research

P.O. Box 338

$6700 \mathrm{AH}$ Wageningen

The Netherlands

boelie.elzen@wur.nl

${ }^{b}$ Wageningen UR Livestock Research

P.O. Box 338

$6700 \mathrm{AH}$ Wageningen

The Netherlands

bram.bos@wur.nl

${ }^{1}$ Present Address: Wageningen UR Plant Research | Field Crops, P.O. Box 430, 8200 AK Lelystad, The Netherlands 


\title{
The RIO approach: Design and anchoring of sustainable animal husbandry systems
}

\begin{abstract}
This paper discusses an approach to develop new 'integrally sustainable' animal production systems and stimulate their uptake in practice. It consists of a design approach called RIO, and a set of 'anchoring' activities to stimulate their uptake in niches and in the regime. In the period 2001-2015 we have applied the approach in various animal production sectors, and adapted and improved it while doing. The general aim of the paper is to assess the applicability of the RIO/anchoring approach to induce sustainability transitions. We conclude that RIO is especially suited for areas characterised by a 'heterogeneous' set of sustainability challenges (in our case, environmental burden, animal welfare, public acceptance, profitability). A RIO approach can then render 'integrally sustainable' alternatives that generate wide interest in the regime. Anchoring activities can successfully stimulate a variety of initial changes. This does not suffice, however, and a conducive institutional environment is key to facilitate the initial uptake of the novel systems. With relatively simple and cheap financial instruments, governments can help to create such a conducive environment.
\end{abstract}

\section{Keywords}

Sustainable design; Reflexive Interactive Design (RIO); Anchoring of Sustainable Innovations; Transition stimulation; Animal husbandry.

\section{Highlights}

- RIO/anchoring development, based on experiences from 9 cases over a 15 -year period.

- The RIO approach is useful to design radically different sustainable novelties.

- Anchoring activities can successfully induce wider uptake of such novelties.

- $\mathrm{RIO} /$ anchoring is especially suited for heterogeneous sustainability challenges. 


\section{Introduction}

\section{The welfare state challenge for animal production}

Since World War II, welfare states have modernised rapidly to provide their citizens with a variety of services, including food, water, energy, housing, mobility, etc. Gradually, the negative sides of this development became manifest and recognized, including pollution, global warming, inequity, etc. This leads to a major challenge for welfare states to address these problems, without endangering the provision of the services (Wittmayer et al. 2014).

This general challenge is reflected in the area of food production, more specifically animal production, that is addressed in this paper. It is the responsibility of the welfare state to provide its citizens with a sufficient supply of food and, at the same time, to ensure that this food is produced in a sustainable manner. In a densely populated country like the Netherlands, this has become a major issue because the environmental burden and other externalities of food production are directly felt by many citizens.

After the second world war, the Dutch government followed a strong policy to modernize agriculture to make it more effective and more productive. Especially in the domain of animal production, successes were large, with the Netherlands becoming the world's third largest exporter of dairy products and the fourth largest exporter of meat (Eurostat 2014). Thus, animal production has become an economic factor of major importance.

However, there is a serious downside to this economic success. In the 1970s and 1980s animal production became seen as a major contributor to acidification and eutrophication, and (later) as a major source of GHG-emissions. In the 1990s, the sector came under further attack because of issues related to animal welfare. This became even stronger in the late 1990s when there was a series of outbreaks of contagious animal diseases, including BSE, classical swine fever and avian influenza. Various well-known people raised their voices, including former 
agricultural banker Herman Wijffels who - in an advice to the government - called for no less than a 'redesign of the sector' (Wijffels 2001).

The government came under increasing pressure to address these issues but did not want to jeopardize the economic importance of the sector. In response, it gradually enforced stricter regulations for animal production, and commissioned research to develop more effective solutions. From the late 1990s onward, the government started to promote a transition towards a sustainable agriculture (Slingerland and Rabbinge 2009). By 2008, this culminated in a general government vision, that by 2023 the Dutch animal production sector should be 'integrally sustainable', i.e. sustainable on all relevant dimensions, including environment, animal welfare, public acceptance and economic feasibility (Verburg 2008). To achieve this, as the ministry white paper explicitly stated, would require a 'system innovation'. Various research institutes were expected to provide the building blocks for this radical change and to play a role in the required transition processes.

\section{WLR approach to address the challenge}

Around the year 2000 our institute, Wageningen UR Livestock Research (WLR), ${ }^{2}$ was assigned the task to address the animal production challenge. WLR is an applied research institute and, in the period described, a large proportion of the research budget came directly from the Ministry of Agriculture (now part of the Ministry of Economic Affairs), based on an annual research programme in accordance with policy priorities.

In our own terms, we faced a transition challenge and were inspired by preliminary findings from transitions research, that had just started at the time. This emerging field had rendered two approaches to tackle sustainability challenges, notably Strategic Niche Management (Hoogma et al. 2002) and Transition Management (Rotmans et al. 2000). However, these

\footnotetext{
${ }^{2}$ In 2000, WLR had a different name (ID Lelystad) but for the sake of simplicity we use the name WLR for the whole period.
} 
poorly fitted the heterogeneous sustainability challenges of the animal production sector. Major shortcomings were the lack of attention for the genesis of sustainable novelties and for the uptake of these novelties in an existing regime.

We therefore set out to develop our own approach to address the challenge in the animal production sector. Following Wijffels' suggestion, also voiced by many others in the field, we focussed on a redesign of animal husbandry systems. This led to the development of the RIO approach, a Dutch acronym for "Reflexive Interactive Design." We have applied this approach to various animal sectors and developed it further to take account of what was learned in previous applications.

To stimulate the uptake of the new designs in practice, we were inspired by the Multi-Level Perspective (MLP) and the idea that novelties need a period of tinkering and learning in niches before they can start transforming an existing regime (e.g. Geels 2002). The approach of Strategic Niche Management (SNM), that was built on the MLP, provided recommendations on how to organise such learning processes (Hoogma et al. 2002).

However, the actual uptake of radical alternatives by a system or regime was an understudied aspect in transitions studies (Smith 2007). Therefore, in the beginning we took rather intuitive actions to stimulate the uptake of the novel husbandry designs, based on insights and reflections to facilitate effective reformism (Roep et al. 2003), niche development (Hoogma et al. 2002) and ideas on inducing transitions from various sources (e.g. Elzen and Wieczorek 2006, Farla et al. 2012). Gradually, we developed a more systematic approach which, also based on the study of another sector (glasshouse horticulture) led to the elaboration of the concept of 'anchoring' (Elzen et al. 2012a).

This, eventually, resulted in an encompassing approach that consists of the design of new, sustainable animal husbandry systems (using RIO) and a strategy to stimulate the wider 
uptake of such systems (based on the concept of 'anchoring'). By applying this combination in various animal sectors over the past 15 years, we learned that these two parts should not be treated as independent steps that follow each other. It appears that what happens in the design phase, can be a strong asset to simulate later take-up.

Since we started our programme, the two approaches that we discarded initially for our purposes (SNM and TM) have been developed further, and so has our approach. For $\mathrm{RIO} /$ anchoring this renders the question what its unique features are and how this affects its applicability as a tool to induce and stimulate transitions towards sustainability. This is the main research question that we will address in this paper.

In the next section, we will first discuss the theoretical background for both RIO and anchoring, and we will describe the methodology used for this paper. Section 3 describes the application of this combined approach in various domains, focussing on modifications made on the basis of earlier experiences. In section 4 we will discuss to what extent the overall ambition of the RIO/anchoring combination - to induce system innovation in the animal production sector - has been realised. Section 5 addresses the main objective of this paper, i.e. to assess the general usefulness of the approach, also by comparing it to other approaches with comparable objectives, notably the SNM, TM and AD\&US co-design approach. We end with a number of general conclusions.

\section{Theoretical and Methodological background}

\section{The RIO approach}

Details of the RIO approach have been described elsewhere (Bos et al. 2011, Bos and Groot Koerkamp 2009, Bos et al. 2009). Here we only describe the main elements that feature in the following sections, and to be able to demonstrate how it was developed further after using the approach in various animal production sectors. 
Our ambition from the beginning was to design 'integrally sustainable' husbandry systems, i.e. sustainable on all relevant dimensions. Thus, very explicitly, we tried to move away from a trajectory of incremental change that had characterized innovation in the sector in the preceding decades, as such an approach cannot be expected to solve the heterogeneous sustainability problems in agriculture (e.g. Elzen et al. 2012b). We deliberately chose an approach that targeted a radical redesign, but that would also have a fair chance of being picked up in the existing system.

Around the year 2000, when we started our design activities for sustainable animal production, we were inspired by a then recently concluded national Dutch programme by the title 'Sustainable Technology Development' (STD; Weaver et al. 2000). The general STD approach was to let heterogeneous stakeholders jointly develop visions of a sustainable future. Subsequently, these visions were 'backcasted' into smaller steps that should be taken to realise that future, starting from the present. The problem for our purposes was that STD targeted the long-term (app. 40 years) while the problems in animal production were such that solutions were required much faster. Furthermore, STD targeted the scale of complete production-consumption systems (e.g. food, energy) while our case focused on a specific production sector where new designs were called for. The idea of developing future visions, however, did seem relevant and was included in our initial approach.

Our design approach was based on the engineering approach of 'Structured Design' (Cross 2008, Siers 2004, Van den Kroonenberg and Siers 1998), which we modified to be able to apply it in an interactive fashion with a diversity of stakeholders. An important starting point for structured design is the Brief of Requirements for the system to be designed. In our cases, this addressed the sustainability challenge and separate briefs were formulated for the farmer, the animal, the citizen/consumer, and the environment. Requirements were quantified as 
much as possible, they were set an ambitious level, and all of them had to be fulfilled in the design. Thus, we attempted to minimize trade-offs between different sustainability aspects.

The basic chronology of the initial RIO approach is presented in Figure 1. It consists of three main phases, each divided into several steps. Although they follow each other in time, there may be some jumping back and forth between these phases and the individual steps, depending upon results and insights from later phases or steps.

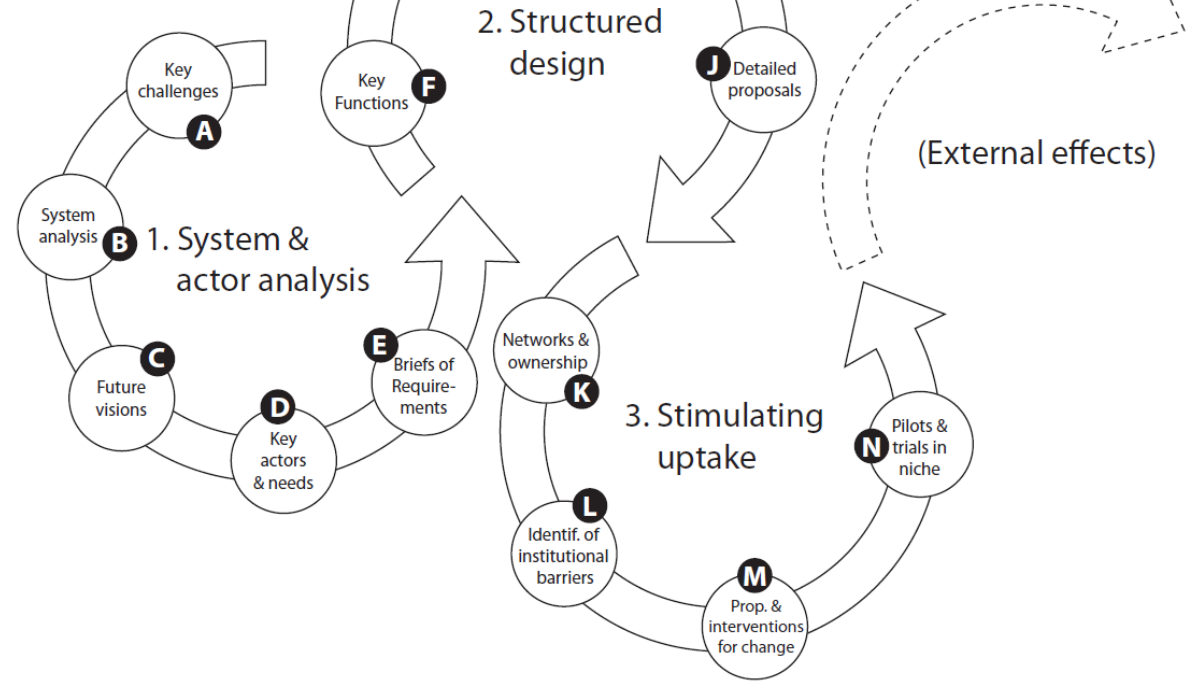

Figure 1: General RIO approach (adapted from Bos et al. 2009).

The three phases in RIO are:

1. Performing a system and actor analysis: a systematic analysis of the current structural arrangements of the animal production system at hand, and the needs of key actors involved. This is done to open up both the 'problem space' and the 'space for solutions' (Bos et al. 2009).

2. Designing new systems or arrangements, using the approach of Structured Design (Cross 2008, Siers 2004, Van den Kroonenberg and Siers 1998), but in an interactive fashion. 
This interaction, involving various types of stakeholders, should ensure the incorporation of practical and tacit knowledge, and to prevent a research bias with respect to the values underlying the design. This should result in feasible and attractive concepts in the eyes of stakeholders (to facilitate uptake), while yet having ambitious sustainability objectives.

3. Stimulating uptake: Initiate and support niche developments and regime changes to stimulate uptake of the novel designs. To achieve this, we used insights to facilitate effective reformism (Roep et al. 2003) and niche development (Hoogma et al. 2002). The combination in RIO of a thorough system analysis (phase 1) and a structured design approach (phase 2) should make it especially appropriate to limit the historical trade-offs between seemingly conflicting needs (e.g. between animal welfare and production cost) and the system failures that had emerged in the incumbent system in preceding decades.

\section{Anchoring activities - stimulating wider take-up}

Having applied RIO in different sectors, our ideas on stimulating wider take-up gradually became more concrete. Also based on work in another sector (greenhouse horticulture), Elzen et al. (2012a) have proposed an approach that builds on the concept of anchoring. They have defined anchoring as follows.

"Anchoring is the process in which a novelty becomes newly connected, connected in a new way, or connected more firmly to a niche or a regime. The further the process of anchoring progresses, meaning that more new connections supporting the novelty develop, the larger the chances are that anchoring will eventually develop into durable links." (Elzen et al. 2012a, p.3)

Building on a distinction between three constituent components of a regime, notably technical, network and institutional components (Geels 2004), the authors distinguish three forms of anchoring. These are technological anchoring, network anchoring and institutional 
anchoring (Elzen et al. 2012a, p.4-6). Technological anchoring takes place when the technical characteristics of a novelty (e.g. new technical concepts) become defined by the actors involved and, hence, become more specific to them. Network anchoring means that the network of actors that support the novelty changes, e.g. by enrolling new producers, users or developers. Institutional anchoring relates to the institutional characteristics of the novelty, i.e. the new rules that govern its further development and uptake. Institutional anchoring implies that developments within a niche or regime become translated into adapted or new rules that govern, at least temporarily, the activities of both niche and regime actors.

In their paper, the authors use the anchoring framework as an analytical tool to analyse an ongoing innovation process. In the RIO approach, following a suggestion made by these authors, we have used it as a diagnostic tool. The distinction of three forms of anchoring made us aware that each of these was needed to stimulate uptake of the designs. This prompted us to undertake specific action when certain forms of anchoring were lagging or lacking.

Thus, RIO seeks to combine the design of new sustainable animal husbandry systems with efforts to stimulate the uptake of these new designs in practice. Concerning the latter, the MLP makes us aware that there is a need for tinkering, learning and further development (in niches; e.g. Schot and Geels 2008), as well as initiating structural reform in the incumbent regime. Both of these are targeted in the RIO/anchoring combination (e.g. Bos et al. 2011).

\section{Methodology}

In the period 2001-2015 we have used the RIO/anchoring combination for various types of animal production systems, of which Table 1 gives an overview. Some of these projects were carried through all the way, up until anchoring activities, while other were terminated prematurely, mostly because of research funding reasons. The long period for some of the 
projects indicates that anchoring activities have continued for a long time. The last column in the table shows for each project which phases and steps were attained.

Table 1: Application of RIO for various animal husbandry systems

\begin{tabular}{|c|c|c|c|}
\hline & $\begin{array}{l}\text { Project name (English } \\
\text { translation) }\end{array}$ & Period & $\begin{array}{l}\text { Phase / steps } \\
\text { attained }\end{array}$ \\
\hline Pig fattening & $\begin{array}{l}\text { Animal Centred Design; } \\
\text { later called Pigs in Comfort } \\
\text { Class }\end{array}$ & $2001-2010$ & $\begin{array}{l}\text { Pilots and trials in } \\
\text { niche; experimental } \\
\text { pilot pigsty }\end{array}$ \\
\hline Laying hens & Laying Hen Husbandry & $2003-2010$ & $\begin{array}{l}\text { Market concept; } \\
\text { commercially operated } \\
\text { henhouses; external } \\
\text { effects }\end{array}$ \\
\hline Dairy Cows & Cow Power & $2007-2015$ & $\begin{array}{l}\text { Pilots and trials in } \\
\text { niche; commercially } \\
\text { operated pilot } \\
\text { cowhouse }\end{array}$ \\
\hline $\begin{array}{l}\text { Pig farming (sows, } \\
\text { piglets and pig } \\
\text { fattening) }\end{array}$ & Pork Opportunities & $2008-2014$ & $\begin{array}{l}\text { Pilots and trials in } \\
\text { niche; commercially } \\
\text { operated pilot pigsty }\end{array}$ \\
\hline Laying hens & Well-Fair Eggs & $2009-2015$ & Networks \& ownership \\
\hline $\begin{array}{l}\text { Broilers (chickens } \\
\text { for meat } \\
\text { production) }\end{array}$ & Broilers with Taste & $2009-2015$ & $\begin{array}{l}\text { Pilots and trials in } \\
\text { niche; commercially } \\
\text { operated pilot } \\
\text { henhouse }\end{array}$ \\
\hline Rabbits & Rabbits on Course & $2010-2015$ & $\begin{array}{l}\text { Networks \& ownership; } \\
\text { experiments with } \\
\text { partial innovations }\end{array}$ \\
\hline Goats & Goats Move Ahead & $2011-2013$ & $\begin{array}{l}\text { Networks \& ownership; } \\
\text { experiments with }\end{array}$ \\
\hline
\end{tabular}




\begin{tabular}{|l|l|l|l|}
\hline & & & partial innovations \\
\hline Veal calves; & Several smaller projects & $2010-2012$ & System analysis \\
turkeys; ducks & & & \\
\hline
\end{tabular}

To stimulate wider uptake, we initially rather intuitively carried out various activities, based on general insights from transition and innovation studies. In the course of time we developed the concept of anchoring and published an article on it, where anchoring was developed as an analytical tool, already indicating that it could also be used as a prescriptive tool (Elzen et al. 2012a). In later RIO projects we used it as such by systematically carrying out a number of activities that addressed the three forms of anchoring. Our concrete activities to stimulate anchoring were very varied, including 'roadshows' to present results to various stakeholders, lectures, building consortia, making proposals for follow-up projects (with stakeholders), advising follow-up projects by others, etc.

As we will discuss below, RIO and anchoring are strongly connected since what happens in the RIO phase, also affects the anchoring phase. To optimise the effectiveness of this connection, we anticipate anchoring already in the RIO phase as follows:

- Casting of RIO participants for the design phase (based on the system and actor analysis in the first phase; cf. Figure 1). We seek to identify farmers and organisations who have a 'drive' for change;

- Evaluate intermediary results with a larger group than only participants;

- Build a project advisory group with heterogeneous stakeholders, including policy makers, food-chain corporations, farmers representative organisations, NGOs, etc. They can serve as 'ambassadors' for later institutional anchoring.

In the following section we will discuss how the approach was developed for the successive projects. This is divided into three subsections, the first on the 'system analysis and design 
process', the second on 'anchoring results' and third on 'stimulating anchoring'. The reason to have two subsections on anchoring is that, as described above, our initial attempts at anchoring were rather intuitive which only later was developed into a more systematic approach, which is described in the third subsection. Our experiences in applying RIO/anchoring led to a number of modifications to the initial approach (Figure 1), that eventually resulted in the version depicted in Figure 4.

To assess the applicability of the RIO/anchoring approach, we not only rely on our own experiences but compare our approach with some other approaches with comparable ambitions, notably SNM, TM and the AD\&US co-design approach. This is used to identify some unique features of our approach that helps to identify a specific class of sustainability challenges, that $\mathrm{RIO}$ /anchoring is best suited for.

\section{Using RIO/anchoring in practice: experiences and further development}

\subsection{The analysis and design process}

The first husbandry redesign project, although not yet by the name of RIO, started in 2001 and addressed the raising of pigs for meat production (also called 'pig fattening; Diergericht Ontwerpen 2003, Groenestein and Schouten 2003, De Greef et al. 2011). The project was carried out mostly by researchers, in cooperation with the pig farmers representative organisation LTO, and the Animal Protection Society. It led to the design of a pigsty that was more animal friendly than conventional designs, while it was expected to be moderately more expensive. A demonstration unit was built but it was never adopted by the sector, that considered it an economic risk, with meat prices under pressure. From this project we learnt that it is important to involve farmers directly in the early phases of the design process (De Greef et al. 2011; Bos and Grin 2008). 
In 2003, the next sector addressed was that of laying hens. For this sector, the sense of urgency was larger than for fattening pigs as new EU regulations would prohibit the housing hens in battery cages by the year 2012. Furthermore, the Dutch government intended to forbid beak trimming by 2006. These issues dominated the ensuing project Houden van Hennen (Laying Hen Husbandry; cf. Houden van Hennen 2004, Groot Koerkamp and Bos 2008, Bos 2008, Spoelstra et al. 2013). This project focussed on animal welfare issues, whereas environmental issues got less attention. In this project, chicken farmers played a key role in the design process. This turned out to be an important asset, as several of them played an important role in anchoring (see below).

In the following years, the interest in other sustainability issues gained momentum and in 2008, the government developed the vision that by 2023 the Dutch livestock sector should be ‘integrally sustainable' (Verburg 2008). This was operationalized in later RIO projects by bringing heterogeneous stakeholders together and addressing a wider range of sustainability aspects. This included environmental as well as social and economic requirements like animal welfare, animal and public health, labour conditions and quality of the landscape.

Another important change related to the systemic level at which change was needed. At the turn of the millennium, most stakeholders focused on the farm level. Gradually, however, various stakeholders came to realize that more encompassing changes in the production system at large would be needed to achieve 'integral sustainability'. For instance, new and more sustainable farming systems are often highly dependent on the creation of new market opportunities. As a consequence, later RIO projects also targeted the animal production system at a higher level than the farm..

An important part of the first RIO projects had been the visioning process. It appeared, however, that these visions played a minor role in further steps, nor in anchoring. The new designs themselves appeared to play that role and create wider interest. On this basis, 
visioning was discarded as a separate step, starting with the Pork Opportunities project in 2008.

A challenging aspect has always been the operationalization of sustainability goals. Initially, they were based on a variety of issues that were either discussed in the literature, or that featured in public and policy debates for the animal sector at hand. More recently, the Dutch governance network 'Uitvoeringsagenda Duurzame Veehouderij' (UDV - the name meaning "Action agenda for Sustainable Animal Production" - with members ranging from NGO to industry) defined a set of fifteen long-term sustainability ambitions, to operationalize the members' common view on fully sustainable livestock production (UDV 2013).

Various controversies emerged in our design groups, which made it often difficult to agree on shared courses of action. To tackle this problem, we tried to find a way to involve the participants already in the analysis phase of the project. This resulted in a "Collective System Analysis" (CSA) which should broaden interactive learning among stakeholders in an earlier phase, and make them aware of the relevance of a higher system level (rather than just the farm level). The CSA brings stakeholders together for a day, to analyze the structural barriers and windows of opportunity for innovation of the current system.

The experiences with CSA have been mixed. Our advance expectation had been that the session would stimulate system learning among the participants, which would imply (1) recognizing the multi-causality of recurrent problems, (2) redefining barriers into opportunities, and (3) designing options for collective action. However, as Van Mierlo et al. (2013) report on such a session, learning appeared to be limited in the sense that few innovation opportunities and no options for collective actions were defined. According to these authors, this was largely due to the representation of a large number of value chain stakeholders in the workshops (including major incumbents). 
Another change made was to increase the intensity of interaction in the design phase to stimulate participating stakeholders to feel ownership of the resulting designs and, hence, increase the chances for anchoring. In the final projects, this was improved by holding two interactive design sessions which differed in set-up. For the 'Broilers with Taste' project, Figure 2 shows one of the global designs with various 'subsystems' that resulted from design session I (DS I), and a the more integral and thought-out concept that resulted from DS II.

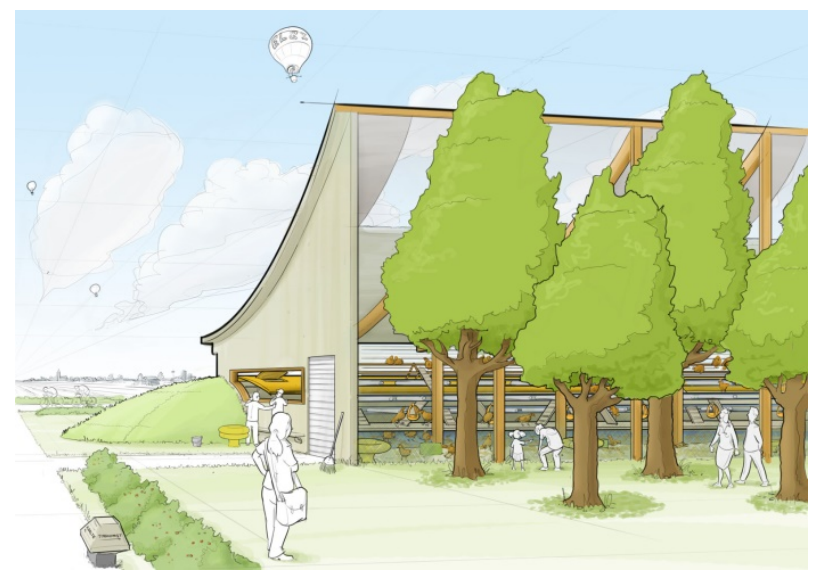

Figure 2: One of the global sketches, resulting from DS I from the 'Broilers with Taste' project (left; 2010), and an impression of the 'Windstreek' design, a more concrete and though-out concept resulting from DS II (right; 2011).

This project resulted in two diverging technical designs for sustainable broiler production at farm level, which were translated into visuals for communication purposes. We targeted two designs as a minimum, to prevent the implicit message that there is only one good solution for integral sustainability. These concepts could be implemented as a whole, as well as by adopting a variety of constituting 'partial innovations'.

Thus, after having applied the RIO approach to a variety of animal production sectors, some general characteristics have been kept (e.g. distinguishing a system analysis, a design and an 
anchoring phase) but various specifics have been altered. Compared to the initial version, the following changes have been made:

- The briefs of requirements (starting point for the design process) cover a wider range of sustainability aspects;

- The focus for change shifted from the farm to the wider animal production system;

- The visioning activity has been skipped;

- The system and actor analysis phase has been changed from a researchers task into partially a collective process with stakeholders;

- The design phase has been split into two subsequent cycles.

This rendered a new version of the RIO/anchoring approach that is depicted in Figure 4 below.

\subsection{Anchoring Results}

In another publication (Bremmer and Bos 2015) we give a detailed account of various anchoring activities and results for a number of RIO projects from Table 1 above. Here we present a brief overview of anchoring results, to be used as a stepping stone towards a more structured anchoring approach that is discussed in section 3.3.

In the initial RIO projects, we did not use the notion of anchoring but targeted the 'uptake' of innovations as a general heuristic (cf. Figure 1). At the time, this was an under-theorised aspect of sustainability transitions (Smith 2007). During these and other projects, we developed the concept of anchoring to address this uptake, distinguishing between technological, network and institutional anchoring (Elzen et al. 2012a).

The design phase of RIO renders two important results, notably designs for a more sustainable animal production system, and a network of people who believe in these and aspire to realize them in practice. Two farmers, who had taken part in one of the first RIO 
projects (Laying Hen Husbandry; Houden van Hennen 2004) took initiatives to actually realise the new designs in their own practice. This resulted in the Lankerenhof (an organic farm; cf. Table 2 for weblink), and the Rondeel ('Roundel' in English, cf. Figure 3. Rondeel has been widely studied, e.g. Klerkx et al. 2010, Zwartkruis 2013, Ch4, Spoelstra et al. 2013). Rondeel operates in the conventional (non-organic) table egg segment and was taken up further in the regime. In the spring of 2015, three commercial Rondeel farms were in operation, and more were planned. Furthermore, one 'mini-Rondeel' with 200 hens is operated in the Amsterdam financial district, partly funded by an environmental NGO.
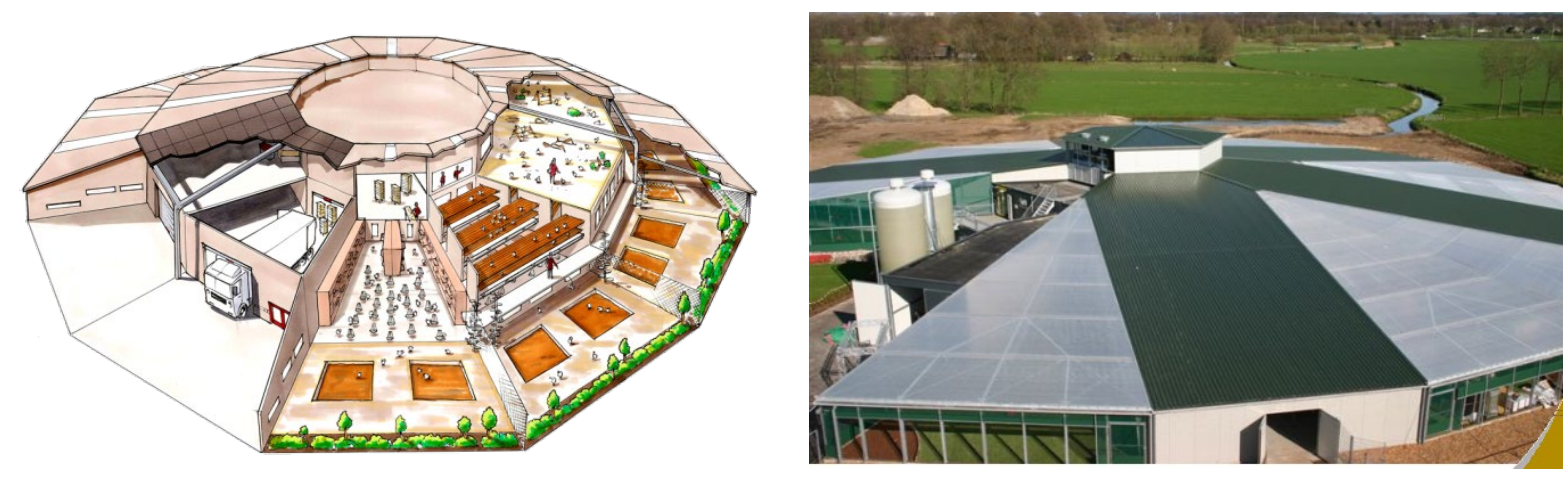

Figure 3: Rondeel design from the "Houden van Hennen" project (left; 2004), and a commercial Rondeel-farm in Barneveld (right; since 2010).

In terms of anchoring, the technological anchoring of the new henhouse designs from the RIO project, was significant among project participants, as well as among relative outsiders in the regime (policy makers, NGOs; On ‘outsiders' cf. Van de Poel 2000).

Network and institutional anchoring, however, were quite weak initially while all three forms of anchoring are needed to initiate regime change. Concerning network anchoring, our experience was that the group of people, who had been involved in the design process, formed a network that, at least for some time after the conclusion of the project, were jointly 
motivated to realise it in practice. For later RIO projects, we therefore chose to pay more attention to involving a broad range of stakeholders in the design phase, to add a second design cycle, and to 'deepen' the design process to stimulate a wide range of participants to feel the owner of the results. An important overall conclusion is that anchoring is not something that only follows design: especially network anchoring and technological anchoring already start during the design phase.

Concerning institutional anchoring, the situation in the early 2000 s was not very conducive to the uptake of sustainable innovations that were more expensive than regular. This was a regime characteristic that was beyond our control. Yet, we were able to contribute to a small change of rules. We had frequent discussions with ministry representatives on the progress and problems of our projects. We raised the issue that some form of government support would be helpful to get sustainable innovations over initial barriers. This coincided with comparable suggestions from others which led the Ministry to develop a new policy instrument by the name of SBIR (small business innovation research). SBIR is an instrument to fund the development of 'societally desirable innovations': new products or processes that fulfil important societal goals, but that are not developed under existing market conditions.

This institutional change strongly affected the network and institutional anchoring from at least four later RIO projects, namely Cow Power, Pork Opportunities, Broilers with Taste and Well-Fair Eggs (cf. Table 1). Consortia originating from the first three projects received SBIR support, and were able to build pilot systems between 2012 and 2015. These specific SBIRtenders themselves originated from experiences with the uptake of earlier RIO-projects which shows how our programme interacted with and influenced policy and policy instruments, and vice versa. It is a clear example of direct interaction between niche and regime developments, that formed a starting point for our approach. 


\subsection{Anchoring as a tool to stimulate uptake}

In our initial approach, we distinguished four different activities that would have to be carried out to stimulate the uptake of the RIO designs. These were loosely based on general insights from SNM and the MLP, notably:

- Create networks and ownership;

- Identify institutional barriers;

- Propose and stimulate interventions for change;

- Realise pilots and trials in a niche.

What would happen afterwards, we considered to be beyond the sphere of influence of the RIO project, as indicated by the dotted arrow denoting 'external effects' in Figure 1.

When our ideas about anchoring took further shape, we developed a more systematic approach. Elzen et al. (2012a) have developed anchoring as an analytical concept, to analyse the uptake of novelties in transition processes. They also suggest, however, that all three forms of anchoring are needed for successful take-up and that it can therefore be used as a diagnostic tool to determine what type of activities are needed in a specific case to stimulate anchoring.

On the basis of our experience in applying the RIO approach in a variety of sectors, we developed a more specific anchoring approach, that addresses all three forms of anchoring and that distinguishes five anchoring activities to initiate a regime change. These activities are:

- Activity 1: Develop and communicate inspiring designs. Design an integrally sustainable new husbandry system with a heterogeneous set of relevant stakeholders, and make these designs widely known to relevant stakeholders in the sector at large, using appealing visuals. 
- Activity 2: Develop sustaining network(s). The creation of (private/public) coalitions that actively strive for follow-ups in practice.

- Activity 3: Create space for niche experiments. Create partnerships and secure funding.

- Activity 4: Stimulate uptake of 'partial innovations', i.e. specific elements from the new designs.

- Activity 5: Create an exemplary new production system. Build and demonstrate a 'full blown' new animal husbandry system in practice (in contrast to only using partial innovations from activity 4).

Below, we briefly elaborate these anchoring activities.

Activity 1: Develop and communicate new designs. The designs result from the $2^{\text {nd }}$ and $3^{\text {rd }}$ phase in RIO (Figure 4). The designs should be radically different from current practice, tackle a range of sustainability issues, and be rooted in farmers' requirements. It is best to have more than one design to allow more stakeholders to be inspired by one of them. These designs should subsequently be made widely known in the sector among relevant stakeholders. Having appealing visuals of the new design (e.g. Figure 2, right, and Figure 3, left) appeared to be a strong asset to stimulate the required technological anchoring.

Activity 2: Develop a sustaining network. The first network consists of those who are involved in the design process. It is helpful if this network consists of representatives from different links in the supply chain, to ensure it addresses heterogeneous sets of barriers. The system analysis, that is carried out as the first phase in RIO (Figure 4), could help identify which stakeholders are important to involve early on. After the design has been completed, it may appear that other actors have to be connected, for which initiatives should be taken. These activities target network anchoring. 
As a general finding, RIO-projects tend to result in a small network of highly involved individuals (including farmers, (employees from) chain partners, service providers and NGOs), who share a common learning experience, engagement with and ownership of typically one of - the design concepts and the principles underlying these. Strong involvement is not a guaranteed result of the approach, and involvement rapidly diminishes with smaller or no involvement in the process. Successful follow-up, requiring at least three to four years of further R\&D and building time, is therefore highly dependent on the continuous enthusiasm and involvement of this particular small group of individuals, and their ability to enrol new partners. The basic design attitude in RIO, important design principles developed during the design phase, as well as the visually attractive and convincing design concepts, play an important role in sustaining the supporting network over a longer period of time.

Activity 3: Create space for experiments. For this activity, we largely relied on the SNM approach (Hoogma et al 2002; Schot and Geels 2008). Even if various stakeholders are inspired by the new designs and want to try it out in practice, they will face a variety of barriers from the incumbent regime. Banks, for instance, are reluctant to finance radically new systems. In our case, the Dutch SBIR scheme was very helpful to make demonstration projects possible and commit market partners to the new designs. Existing regulations may also create barriers. Realizing the first Rondeel henhouse, for instance, was problematic since it didn't fit the existing local regulations that assumed henhouses were of a rectangular shape (Klerkx et al. 2010). Creating space for experiments requires various forms of niche protection (Smith and Raven 2012) which often implies changing the rules of the game and, hence, constitutes an example of institutional anchoring.

Activity 4: Uptake of partial innovations. The resulting design from a RIO project will consist of a variety of 'partial innovations' that address specific requirements, e.g. a more sustainable system to collect manure and urine, or a natural ventilation system. Several of these may well 
be useful in conventional farming systems and various farmers may be inspired to apply them, as our experience shows. It should be noted that also these 'partial innovations' are very different from a conventional system and designed to be considerably more sustainable, preferably on more than one specific dimension. As a result, using them in a conventional system is not easy and requires overcoming several barriers. This is an activity in technological anchoring in the regime, but also in institutional anchoring, since it changes the rules that govern farmers' choices.

Activity 5: Create an exemplary new farming system that targets 'integral sustainability'. This involves structural changes in terms of both hardware (the visualised design) and orgware (the operational procedures at the farm). Although it appears that many farmers may be inspired by a new design on paper, they see a range of barriers when thinking about realizing it in their own practice. Once realized, an exemplary new system can play an important role in taking away such reservations, making it easier for other farmers to follow. This activity thus furthers technological anchoring, but among a larger group of farmers (network anchoring).

To realize such exemplary new husbandry system, especially funding appeared to be a critical issue. The development of Rondeel was funded by a large government grant from a temporary national innovation programme by the name of Transforum, as well as private investments from a leading Dutch poultry equipment manufacturer. Four other take-up initiatives gained funding by winning SBIR tenders, notably Vair (pigs), Star Plus (pigs), Kwatrijn (dairy cows), Windstreek (broilers) (cf. Table 3, except Kwatrijn). The consortia for Vair and Windstreek were based on partnerships that were already established in the preceding RIOprojects, whereas Kwatrijn and Star Plus came from largely new partnerships, including firms that were not involved earlier. As a consequence, especially the Kwatrijn consortium had a long internal struggle on the significance of the design and its potential in the market (Zwartkruis 2013, Ch5). 
Figure 4 gives the latest version of the RIO/anchoring approach, including the five anchoring activities.

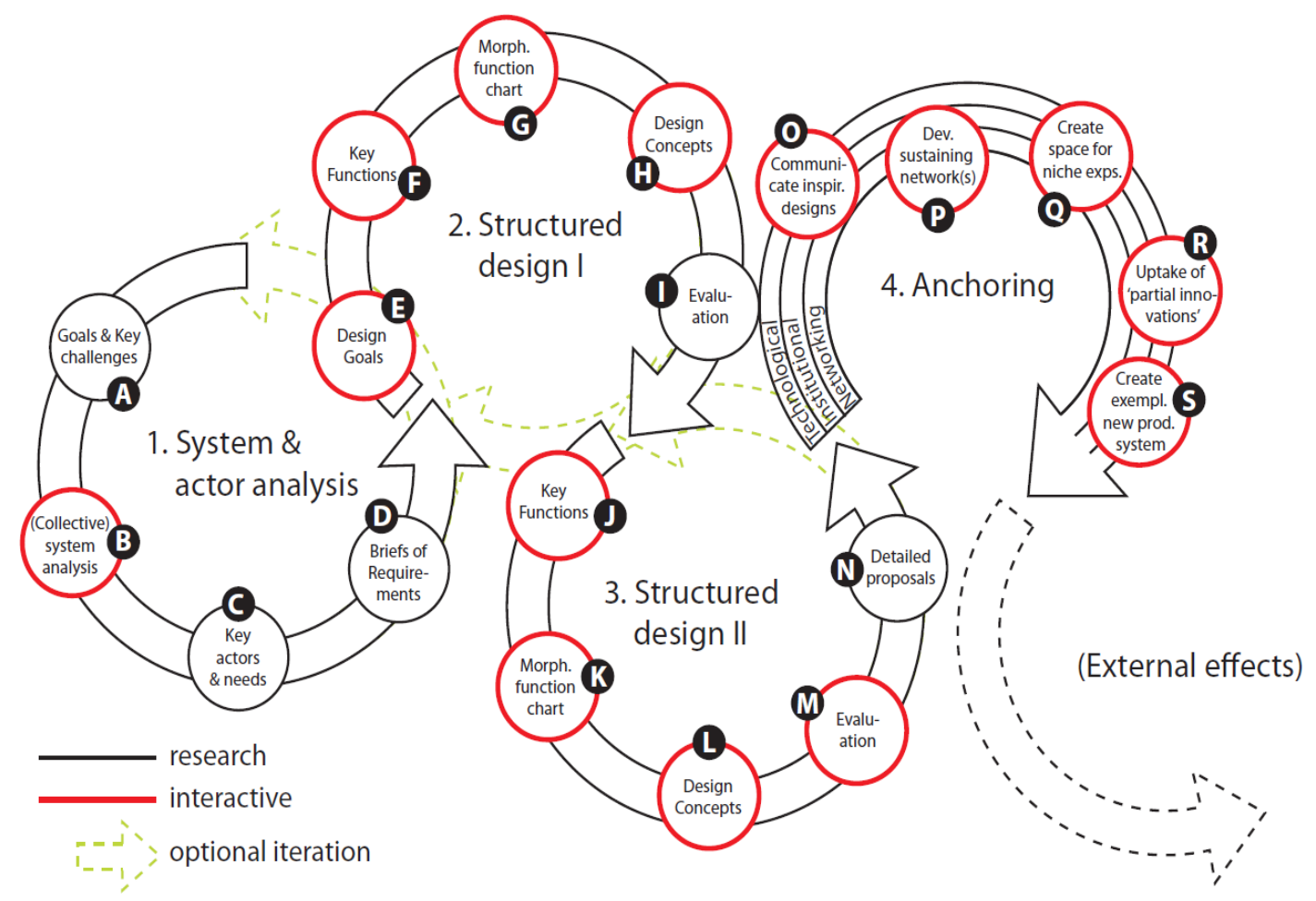

Figure 4: RIO version 2, as practiced in the Well-Fair Eggs and Broilers with Taste projects. Note: initial network and technological anchoring actually already start in the design phase.

A recent paper analyses the uptake of three RIO-projects in more detail (Bremmer and Bos 2015). In Table 2, we present a brief overview of four exemplary RIO projects, addressing each of the anchoring activities above for each project. It also lists the overall outcome in terms of initiating regime change (in the bottom row) which is further discussed in the next section. 
Table 2: Overview of four RIO-projects and their anchoring.

\begin{tabular}{|c|c|c|c|c|}
\hline Project title & $\begin{array}{l}\text { Pigs in Comfort } \\
\text { Class }\end{array}$ & $\begin{array}{l}\text { Laying hen } \\
\text { husbandry }\end{array}$ & Pork Opportunities & $\begin{array}{l}\text { Broilers with } \\
\text { Taste }\end{array}$ \\
\hline Project period & $\begin{array}{l}2001-2003, \\
\text { anchoring until } \\
2010\end{array}$ & $\begin{array}{l}\text { 2002-2004, } \\
\text { anchoring until } \\
2010\end{array}$ & $\begin{array}{l}\text { 2008-2010, } \\
\text { anchoring until } 2014\end{array}$ & $\begin{array}{l}2009-2011, \\
\text { anchoring until } \\
2015\end{array}$ \\
\hline $\begin{array}{l}\text { Animal } \\
\text { species }\end{array}$ & Fattening pigs & $\begin{array}{l}\text { Laying hens (esp. } \\
\text { for table eggs) }\end{array}$ & $\begin{array}{l}\text { Pigs (sows, piglets, } \\
\text { fattening) }\end{array}$ & $\begin{array}{l}\text { Broilers (chickens } \\
\text { for meat } \\
\text { production) }\end{array}$ \\
\hline Design scope & Barn & Farm & Farm/barn, supplies & $\begin{array}{l}\text { Farm/barn }+ \\
\text { surrounding parts } \\
\text { of the chain } \\
\text { (supplies + market) }\end{array}$ \\
\hline $\begin{array}{l}\text { Dimensions of } \\
\text { sustainability } \\
\text { addressed }\end{array}$ & animal welfare & $\begin{array}{l}\text { animal welfare; } \\
\text { farmer needs; } \\
\text { citizen perspectives }\end{array}$ & $\begin{array}{l}\text { animal welfare \& } \\
\text { health; ecological } \\
\text { footprint (local and } \\
\text { global); farmer needs }\end{array}$ & $\begin{array}{l}\text { animal welfare \& } \\
\text { health; ecological } \\
\text { footprint (local and } \\
\text { global); farmer } \\
\text { needs; economy; } \\
\text { chain efficiency; }\end{array}$ \\
\hline $\begin{array}{l}\text { Weblink to } \\
\text { project report }\end{array}$ & $\begin{array}{l}\text { edepot.wur.nl/4197 } \\
7 \\
\text { (in Dutch only) }\end{array}$ & edepot.wur.nl/5545 & $\begin{array}{l}\text { edepot.wur.nl/13565 } \\
6 \\
\text { (in Dutch only) }\end{array}$ & edepot.wur.nl/5545 \\
\hline $\begin{array}{l}\text { Weblnks to } \\
\text { follow-up } \\
\text { projects }\end{array}$ & & $\begin{array}{l}\text { www.lankerenhof.nl } \\
\text { www.rondeel.org }\end{array}$ & www.vair.nl & www.windstreek.eu \\
\hline \multicolumn{5}{|c|}{ Anchoring activities } \\
\hline $\begin{array}{l}\text { Activity 1: } \\
\text { Inspiring design }\end{array}$ & $\begin{array}{l}\text { Not by pig farmers, } \\
\text { but embraced by } \\
\text { NGOs/politics. }\end{array}$ & $\begin{array}{l}\text { Initially on a very } \\
\text { small basis (few } \\
\text { farmers, NGOs, } \\
\text { research) and } \\
\text { strongly contested. } \\
\text { Rondeel design }\end{array}$ & $\begin{array}{l}\text { Principles behind } \\
\text { designs have } \\
\text { received wider } \\
\text { adoption; design } \\
\text { concepts themselves } \\
\text { played marginal role; }\end{array}$ & $\begin{array}{l}\text { Yes, strong support } \\
\text { from heterogeneous } \\
\text { actors (farmers, } \\
\text { NGOs, } \\
\text { governments, some } \\
\text { chain partners), but }\end{array}$ \\
\hline
\end{tabular}




\begin{tabular}{|c|c|c|c|c|}
\hline & & $\begin{array}{l}\text { played an } \\
\text { important role in } \\
\text { realization of } \\
\text { Rondeel in practice. }\end{array}$ & not contested. & also contested \\
\hline $\begin{array}{l}\text { Activity 2: } \\
\text { Sustaining } \\
\text { network }\end{array}$ & $\begin{array}{l}\text { Yes; partnership of } \\
\text { supermarket and } \\
\text { slaughterhouse for } \\
\text { 1-star initiative. }\end{array}$ & $\begin{array}{l}\text { Yes; Rondeel, and } \\
\text { to some extent } \\
\text { Lankerenhof }\end{array}$ & $\begin{array}{l}\text { Yes, Innovation } \\
\text { Programme } \\
\text { Varkansen, Vair } \\
\text { pigsty, network Pig } \\
\text { toilet }\end{array}$ & $\begin{array}{l}\text { Yes, Windstreek } \\
\text { consortium }\end{array}$ \\
\hline $\begin{array}{l}\text { Activity } 3 \text { : } \\
\text { Space for } \\
\text { experiments }\end{array}$ & $\begin{array}{l}\text { Yes: led to } \\
\text { intensive } \\
\text { cooperation } \\
\text { between farmers' } \\
\text { organization and } \\
\text { Animal Protection } \\
\text { Society (APS); } \\
\text { better life quality } \\
\text { label by APS } \\
\text { inspired by project; } \\
\text { led to new financial } \\
\text { stimuli (SBIR, } \\
\text { subsidies); led to } \\
\text { more space in } \\
\text { regulations }\end{array}$ & $\begin{array}{l}\text { Yes: better life } \\
\text { quality label of APS } \\
\text { inspired by project; } \\
\text { led to new financial } \\
\text { stimuli (SBIR, } \\
\text { subsidies); led to } \\
\text { more space in } \\
\text { regulations }\end{array}$ & $\begin{array}{l}\text { Yes: led to } \\
\text { Innovation } \\
\text { Programme } \\
\text { Varkansen and } \\
\text { cooperations like the } \\
\text { 'Truffelcoalition'; } \\
\text { 'standardized' } \\
\text { thinking within sector } \\
\text { in terms of fulfilling } \\
\text { needs of farmer, } \\
\text { animal, } \\
\text { citizen/consumer and } \\
\text { environment. }\end{array}$ & No \\
\hline $\begin{array}{l}\text { Activity 4: } \\
\text { Uptake of } \\
\text { 'partial } \\
\text { innovations' }\end{array}$ & $\begin{array}{l}\text { Yes, at least one: } \\
\text { comfort class pilot } \\
\text { pigsty (2006- } \\
\text { 2009), a shared } \\
\text { experiment of } \\
\text { farmers' } \\
\text { organization and } \\
\text { Animal Protection } \\
\text { Society. }\end{array}$ & $\begin{array}{l}\text { Yes, low density } \\
\text { housing in a } \\
\text { commercial } \\
\text { pigfarm. Also } \\
\text { uptake of features } \\
\text { like functional } \\
\text { differentiation of } \\
\text { space, more space } \\
\text { per pig, daylight, } \\
\text { chain compacting. }\end{array}$ & $\begin{array}{l}\text { Yes, pig toilet (in } \\
\text { terms of R\&D-effort) }\end{array}$ & $\begin{array}{l}\text { Yes, brooding hood } \\
\text { adopted by } \\
\text { industrial enterprise } \\
\text { as separate product } \\
\text { (2015). }\end{array}$ \\
\hline Activity 5: & No. Ideas have & Yes. Lankerenhof & Yes. Star Plus & Yes. Project led to \\
\hline
\end{tabular}




\begin{tabular}{|c|c|c|c|c|}
\hline $\begin{array}{l}\text { Exemplary new } \\
\text { husbandry } \\
\text { system }\end{array}$ & $\begin{array}{l}\text { been adopted in 1- } \\
\text { star initiative to } \\
\text { improve animal } \\
\text { welfare in existing } \\
\text { barns }\end{array}$ & $\begin{array}{l}\text { (organic) and } \\
\text { Rondeel henhouse. } \\
\text { The latter is } \\
\text { successfully } \\
\text { introduced in the } \\
\text { regular market and } \\
\text { has a sustainable } \\
\text { business model, } \\
\text { based on a different } \\
\text { supply chain model. }\end{array}$ & $\begin{array}{l}\text { concept (pilot), Vair } \\
\text { pigsty (niche concept } \\
\text { in commercial } \\
\text { operation) }\end{array}$ & $\begin{array}{l}\text { Windstreek- } \\
\text { initiative, that } \\
\text { opened first pilot } \\
\text { pigfarm in } \\
\text { November } 2015 \text {. } \\
\text { Has commercial } \\
\text { potential as a whole } \\
\text { and in some of its } \\
\text { vital parts. }\end{array}$ \\
\hline \multicolumn{5}{|c|}{ Outcome: initiating regime change } \\
\hline & $\begin{array}{l}\text { Yes; project led to } \\
\text { 1-star initiative of } \\
\text { supermarket \& } \\
\text { slaughterhouse } \\
\text { (slightly better } \\
\text { welfare for } 1 \text { million } \\
\text { pigs); project } \\
\text { catalysed Better } \\
\text { Life quality label of } \\
\text { Animal Protection } \\
\text { Society }\end{array}$ & $\begin{array}{l}\text { Yes; Project led to } \\
\text { successful separate } \\
\text { chain in the market } \\
\text { (Rondeel), but } \\
\text { scale is still limited } \\
\text { and the incumbent } \\
\text { system is left } \\
\text { unchanged; project } \\
\text { catalysed Better } \\
\text { Life quality label of } \\
\text { Animal Protection } \\
\text { Society }\end{array}$ & $\begin{array}{l}\text { No. Hitherto effects } \\
\text { only at the niche } \\
\text { level. }\end{array}$ & $\begin{array}{l}\text { No. Hitherto effects } \\
\text { only at the niche } \\
\text { level. }\end{array}$ \\
\hline
\end{tabular}

\section{Initiating regime change}

The objective of the programme 'Designs for System Innovation', of which RIO was a part, was to make a significant contribution to a structural rearrangement (a system innovation) of animal husbandry in the Netherlands. This should contribute to the policy goal of making animal husbandry integrally sustainable by 2023 .

From Table 2, we can infer that a system innovation (or regime change, in MLP terms) in livestock production hitherto has not been attained for any of the animal categories. Of 
course, this can be expected, since regime changes typically take a generation or more to realize, while the projects ran mostly within the past decade.

Nevertheless, as is observed in connection with the two early projects "Pigs in Comfort Class" and "Laying Hen Husbandry", some interesting and meaningful changes at the level of the regime emerged in association with these projects (Bos et al. 2011, Bos and Grin 2012). These were: (1) the development of an animal welfare quality label for animal products by the Animal Protection Society, combined with the opening up of its highest level (three stars) for non-organic, integrally sustainable systems like Rondeel; (2) an agreement between Albert Heijn and Vion (the largest supermarket and the largest slaughterhouse in the Netherlands) to lift the bottom level for pork to the 1 star-level, affecting 1 million pigs a year; and (3) the development of several new financial policy instruments to accelerate the adoption of more sustainable technologies, including SBIR.

These changes cannot be attributed to RIO/anchoring alone but the outcomes of the projects did play an important role (Bremmer and Bos 2015). This demonstrates that the $\mathrm{RIO}$ /anchoring approach, as a reflexive learning process, is not limited to the conceptualization of novelties and the initiation of niche experiments, but can also trigger changes within the regime at large.

It remains to be seen, however, whether these changes are a prelude to structural regime changes that lift the sector as a whole to higher levels of sustainability on various dimensions. The opposite might also happen, and initial changes might also solidify the current regime by taking away the societal and political sense of urgency.

For a number of reasons, however, we think that the first two projects in Table 2 may well initiate a regime change, and that's why we scored them 'yes' in the associated last row. A general reason is the remaining policy target for an integrally sustainable animal husbandry in 
2023. Although policy targets come and go, this continues to have a strong effect on current developments, for instance via the UDV-Action Agenda in which heterogeneous stakeholders co-operate to make the sector more sustainable (UDV 2013). Most important, in our view, is that regime-uptake of 'modest' change did not make niche renewal go away. Various farmers and other stakeholders are still tinkering with radically new, sustainable alternatives and feel strongly motivated to make it work. Thus, despite improvements within the regime, the landscape and internal regime pressure for change has not diminished, and niche activity continues to be strong. This is why we think these changes still mark the beginning of a regime change, rather than a defensive move to perpetuate the regime.

\section{Discussion - Assessing the applicability of RIO/anchoring}

The RIO approach was developed with the objective to induce a transition to sustainability in the animal production sector. From transition literature, the two best known approaches with a comparable ambition are Strategic Niche Management (SNM; Schot and Geels 2008; Sengers et al. 2016; Smith and Raven 2012) and Transition Management (TM; Loorbach et al. 2015; Loorbach 2007). In this section, we will compare RIO/anchoring with these approaches to identify important similarities and differences. We do not intend to judge the strength and weaknesses of each approach (that would require a far deeper analysis), but just seek to assess where unique features of RIO/anchoring lie. This will subsequently serve as a stepping stone to discuss the specific applicability of the approach as a tool to induce transitions towards sustainability.

Since RIO, unlike SNM and TM has a focus on design and genesis of 'integrally sustainable novelties' we also include another approach in the comparison that focusses on design. Various approaches are used to re-design and co-design farming systems (for an overview cf. Meynard et al. 2012). Here we are not interested in giving an overview, but to identify 
specific features of RIO/anchoring and to this end we have included one other, more recent design approach in the table for contrast. This concerns a co-design approach, based on intertwining between design and use of novelties (Prost et al. 2012; Cerf et al. 2012; Berthet et al. 2015). It has been developed by some researchers from INRA in France (the National Institute for Agronomic Research) and is here referred to as the AD\&US approach (expressing intertwining between Artefact Design \& Use Situations).

Table 3 presents this comparison. The rows in the table indicate the various activities that we have used in RIO/anchoring and found relevant (or, in one case, discarded). We have rephrased two of the anchoring activities discussed above somewhat to do justice to differences in focus in SNM and TM. The scores indicate which of these activities are an elaborated part of the various approaches. We realise that these scores are somewhat contestable. ${ }^{3}$ The criterion to mark an activity as part of an approach (the $\checkmark$ in the table) is that the literature explicitly describes this as an important part of the approach. We have included an intermediate category "implicit part" (with an "I") for those activities that can be assumed to be part of the approach, but that are not elaborated in the general literature.

Table 3: Comparison of approaches to stimulate transitions to sustainability. $\checkmark=$ elaborated part of the approach; $+=$ contains elements of this part; $-=$ not (elaborated) part; I = implicit part but not systematically described.

\begin{tabular}{|r|c|c|l|l|}
\hline & $\begin{array}{l}\text { RIO \& } \\
\text { Anchoring }\end{array}$ & $\begin{array}{l}\text { Strategic Niche } \\
\text { Management }\end{array}$ & $\begin{array}{l}\text { Transition } \\
\text { Management }\end{array}$ & $\begin{array}{l}\text { AD\&US } \\
\text { approach }\end{array}$ \\
\hline Design activities & & & & \\
\hline $\begin{array}{r}\text { System and actor } \\
\text { analysis }\end{array}$ & $\checkmark$ & $\checkmark$ & I & \\
\hline
\end{tabular}

\footnotetext{
${ }^{3}$ To make the scores more robust, we verified them with a user of each of these approaches.
} 


\begin{tabular}{|c|c|c|c|c|}
\hline $\begin{array}{r}\text { Create long-term } \\
\text { visions }\end{array}$ & - & - & $\checkmark$ & I \\
\hline $\begin{array}{r}\text { Create briefs of } \\
\text { requirements }\end{array}$ & $\checkmark$ & - & - & $\mathrm{I}$ \\
\hline $\begin{array}{r}\text { Design 'partial } \\
\text { innovations' for } \\
\text { subsystems }\end{array}$ & $\checkmark$ & - & $\checkmark$ & $\checkmark$ \\
\hline $\begin{array}{r}\text { Create 'integrally } \\
\text { sustainable' new } \\
\text { designs }\end{array}$ & $\checkmark$ & - & - & - \\
\hline \multicolumn{5}{|l|}{ Anchoring activities } \\
\hline $\begin{array}{l}\text { Distinguish different } \\
\text { types of anchoring }\end{array}$ & $\checkmark$ & + & - & - \\
\hline $\begin{array}{r}\text { Communication: make } \\
\text { new (sub-)systems } \\
\text { widely known }\end{array}$ & $\checkmark$ & I & I & I \\
\hline $\begin{array}{r}\text { Develop sustaining } \\
\text { network(s) }\end{array}$ & $\checkmark$ & $\checkmark$ & $\checkmark$ & $\checkmark$ \\
\hline $\begin{array}{r}\text { Stimulate niche } \\
\text { experiments }\end{array}$ & $\checkmark$ & $\checkmark$ & $\checkmark$ & $\checkmark$ \\
\hline $\begin{array}{l}\text { Stimulate uptake of } \\
\text { 'partial innovations' }\end{array}$ & $\checkmark$ & - & I & $\checkmark$ \\
\hline $\begin{array}{r}\text { Stimulate practice } \\
\text { demonstration of } \\
\text { 'complete' new system }\end{array}$ & $\checkmark$ & $\checkmark$ & $\checkmark$ & - \\
\hline
\end{tabular}

As indicated above, two of the approaches systematically address the design phase, notably RIO and AD\&US, although TM also addresses the design of partial innovations, following a backcasting step (Frantzeskaki et al. 2011). Interestingly, one aspect that is part and parcel of $\mathrm{TM}$, to create long term visions, was initially part RIO but later discarded. We skipped this as 
it appeared in practice that anchoring is also very well possible on the basis of the novel designs themselves, by making appealing visuals and communicating these widely. Like RIO, TM and AD\&US make use of an interactive process with stakeholders in the design approach (co-design; Prost et al. 2012). An important difference, however, is that TM and AD\&US target a 'step-by-step' change process at the level of subsystems as whereas RIO targets an ‘integrally sustainable' new design.

Concerning anchoring, our approach distinguishes three different types (technology, network, institution) which we have found to be a very useful heuristic to identify necessary further stimulation activities. Other approaches do not explicitly make this distinction, although SNM does make a distinction between 'fit-and-conform' and 'stretch-and-transform' strategies that has elements of anchoring (Smith and Raven 2012). The next three anchoring activities in the table (communication, network building and niche stimulation) are part of all approaches. This suggests that these activities are considered key in any approach to stimulate wider uptake.

A crucial feature of RIO and AD\&US is to stimulate the uptake of partial innovations, although this can also be present in TM (e.g. Loorbach et al. 2015). The relevance of this activity may well be related to sectors that face challenges on a range of sustainability dimensions, which is especially true for the agricultural sectors for which RIO/Anchoring and AD\&US have been developed (emission of pollutants, greenhouse gases, stench, animal welfare). This implies that 'integrally sustainable' new designs, that RIO targets, will feature a range of novelties and individual farmers may only be interested in some of those. For a variety of other sectors, with a more 'focussed' sustainability challenge, this is less relevant. The risk of the wider uptake of partial innovations, however, is that the overall objective of achieving 'integral sustainability’ may disappear from sight. For that reason, the final activity, to demonstrate a 'complete' new system that combines all novelties, is crucial for our 
approach to demonstrate an integrally sustainable new farming system in a farmer's practice. TM and SNM also feature demonstration of 'complete systems' but these are not necessarily 'integrally sustainable' as this may well relate to a 'subsystem' that became the focus in the preceding process.

From this comparison with other approaches, we conclude that RIO/anchoring combines a set of activities that make it especially suited for sectors that feature a range of heterogeneous sustainability challenges, for (some of) which no sustainable alternatives have yet been demonstrated and that should be developed from scratch. Such sectors are often characterized by ‘wicked problems' (Rittel \& Webber 1973, 155-169) or 'persistent problems' (Schuitmaker 2012). These are long-standing problems that are difficult to solve, partially because solutions for one type of problem tend to increase another type of problem. In such cases, a combination of the RIO design approach with a set of anchoring activities provides an effective strategy to design 'encompassing' solutions and to stimulate a wide range of renewal activities in such a sector, that may lay the seeds for a sustainability transition.

In private communications, e.g. following presentations on the approach, it has sometimes been suggested this approach is 'typically Dutch', fitting the Dutch culture of 'doing things together'. We do not think this is the case, however, since our experiences are that in the starting phases participants clearly have very diverging views on what is possible or desirable. As described above, various controversies have emerged in using RIO. The strength of the process is that it helps heterogeneous stakeholders to take a step away from short term conflicts and constraints, and search for longer term goals that are shared. The latter are the fundamental starting point for the design process and are eventually exemplified by the resulting designs themselves. People outside the Netherlands have recognized this, and we have had enquiries for further details and support from a diverse set of countries, including Canada, Galapagos and New Zealand. All of these concern the animal production sector. 
From the previous section (initiating regime change) it is evident that RIO/anchoring does not provide a guaranteed route for 'success' (cf. also last row in Table 2). In some cases there are no signs of any significant change at the regime level. This may be a matter of time, though, as for the earlier projects, this took 5-10 years to mature. Furthermore, not all renewal activity in the 'successful' cases can be attributed to RIO/anchoring or to RIO/anchoring only. A general feature of the Dutch animal production sector, that has been present more or less consistently for the past fifteen years, is a strong sense of urgency that is shared by most stakeholders in the sector. There has been and is a strong societal and political pressure for change, which contributes to a general openness towards renewal. This certainly helps to make RIO/anchoring more effective and it would be very illuminating to apply the approach in a situation or country where the sense of urgency is less widely shared.

\section{Conclusion}

Our research question was to assess the applicability of RIO/anchoring as a tool to induce and stimulate transitions towards sustainability. We described how we applied the approach in various animal production sectors, developed it further on the basis of successive experiences and carried out a systematic set of anchoring activities. It is far too soon to talk of a 'transition in the making' but application of the approach did induce a variety of changes that could well mark the beginning of a transition in various animal production sectors. A conducive institutional environment is key to facilitate the further uptake of the novel systems, but with relatively simple and cheap financial instruments like SBIR, governments can help to create such a conducive environment.

By comparing the RIO/anchoring approach with a number of other approaches, that seek to induce transitions, i.e. SNM, TM, and AD\&US, we concluded that our approach is especially suited for domains with 'heterogeneous sustainability challenges'. Such heterogeneous 
challenges not only feature in animal production but also occur in other welfare state domains. Currently, we apply RIO on water management of the Dutch western peat lands, where water boards have increasing difficulties to unite farmer's interests with the prevention of soil subsidence, climate adaptation and nature conservation. Furthermore, we can imagine that RIO/anchoring might be applicable for 'soft' sectors, like health, or aging, that are also characterised by a heterogeneous set of challenges. An important difference with the application in our case is that the 'brief of requirements' would look rather different. But that was also true in our case, compared to the initial 'Structured Design' approach (Cross 2008, Siers 2004), so such a modification seems possible in principle.

Both the RIO part as well as the anchoring part of our approach make important contributions to the general field of transition studies and stimulation of sustainability transitions. This field has largely neglected the genesis of novelties, which is at the heart of RIO. Furthermore, Smith's (2007) diagnosis that the regime uptake of novelties is an understudied aspect is still valid, although some further work has been published (e.g. Ingram 2015). In this area, we have made the contribution to take the analytical concept of anchoring a step further by using it as a diagnostic tool.

We do not want to claim that $\mathrm{RIO} /$ anchoring is unique in all its facets. We already indicated how it builds on STD, MLP, SNM and on the 'Structured Design' approach. Furthermore, its emphasis on reflexivity and redeveloping farming systems are also at the heart of the modern version of Farming Systems Research (e.g. Darnhofer et al. 2012) and more general literature on reflexive governance (Voss et al. 2006).

We do claim, however, that RIO/anchoring provides a unique combination of activities that make it especially suited for a specific class of heterogeneous sustainability challenges. This means that it should not be seen as a replacement for SNM, TM or other design approaches, that have their own strengths. Actually, in many practical cases, a combination of elements 
from different approaches may prove to be most effective. In our case, for instance, our activities to stimulate niche experiments were largely guided by the SNM approach, as indicated above. But we also think that the other approaches can be enriched by our approach, especially by making the distinction between technological, network and institutional anchoring as a diagnostic tool, to identify activities that are required most in the near term.

\section{Acknowledgements}

This paper was funded by the Dutch Ministry of Economic Affairs as part of the KBVI programme "Transitie \& Innovatie" (Transition \& Innovation; KB-16-002.02-001), and the former Knowledge Network on System Innovations (KSI). We also want to thank two anonymous referees and the editors of this special issue, who gave a variety of useful comments to an earlier version of this paper.

\section{References}

Berthet, E.T.A., Barnaud, C., Girard, N., Labatut, J., Martin, G., 2015. How to foster agroecological innovations? A comparison of participatory design methods. Journal of Environmental Planning and Management. DOI:10.1080/09640568.2015.1009627

Bos, A. P., 2008. Instrumentalization Theory and Reflexive Design in Animal Husbandry. Social Epistemology, 22, 29-50.

Bos, A. P. \& Grin, J., 2008. "Doing” Reflexive Modernization in Pig Husbandry: The Hard Work of Changing the Course of a River. Science, Technology, \& Human Values, 33, 480-507.

Bos, A. P. \& Grin, J., 2012. Reflexive interactive design as an instrument for dual track governance. In: Barbier, M. \& Elzen, B. E. (eds.) System Innovations, Knowledge 
Regimes, and Design Practices towards Transitions for Sustainable Agriculture. Paris: INRA-SAD.

Bos, A. P. \& Groot Koerkamp, P. W. G., 2009. Synthesizing needs in system innovation through methodical design. A methodical outline on the role of needs in Reflexive Interactive Design (RIO). In: Poppe, K. J., Termeer, C. \& Slingerland, M. (eds.) Transitions towards sustainable agriculture, food chains and peri-urban areas. Wageningen: Wageningen Academic Publishers.

Bos, A. P., Groot Koerkamp, P. W. G., Gosselink, J. M. J. \& Bokma, S. J., 2009. Reflexive Interactive Design and its application in a project on sustainable dairy husbandry systems. Outlook on Agriculture, 38, 137-145.

Bos, A. P., Spoelstra, S. F., Groot Koerkamp, P. W. G., De Greef, K. H. \& Van Eijk, O. N. M., 2011. Reflexive design for sustainable animal husbandry: mediating between niche and regime. In: Spaargaren, G., Loeber, A. \& Oosterveer, P. (eds.) A transition perspective on sustainable food and agriculture. London: Routledge.

Bremmer, Bart and Bos, Bram, 2015. Creating Niches by applying Reflexive Interactive Design. In Elzen, Boelie, Augustyn, Anna, Barbier, Marc and Van Mierlo, Barbara (eds.), 2015 (forthcoming). AgroEcological Transitions: Changes and Breakthroughs in the Making. Proceedings of the second SISA workshop. Wageningen: Wageningen UR.

Cerf, M., Prost, L., Jeuffroy, M. H. and Meynard, J. M. M., 2012. Participatory design of agricultural decision support tools: taking account of the use situations. Agronomy for Sustainable Development. DOI 10.1007/s13593-012-0091-z.

Cross, N. 2008. Engineering Design Methods - Strategies for Product Design. Fourth Edition, Hoboken, NJ, Wiley.

Darnhofer, Ika, Gibbon, David and Dedieu, Benoit (eds.), 2012. Farming Systems Research into the 21st century: The new dynamic. Dordrecht: Springer. Cf. especially Chapter 1: 
Ika Darnhofer, David Gibbon and Benoit Dedieu. Farming Systems Research: an approach to inquiry. 3-31.

De Greef, K. H., Vermeer, H. M., Houwers, H. W. J. \& Bos, A. P., 2011. Proof of Principle of the Comfort Class concept in pigs. Experimenting in the midst of a stakeholder process on pig welfare. Livestock Science, 139, 172-185.

Diergericht Ontwerpen, 2003. Welzwijn in de toekomst, over varkenswensen voor varkensstallen. Wageningen/Lelystad: Wageningen UR.

Elzen, B., Leeuwis, C. and Van Mierlo, B. C., 2012a. Anchoring of innovations: Assessing Dutch efforts to harvest energy from glasshouses. Environmental Innovation and Societal Transitions, 5, 1-18.

Elzen, Boelie, Barbier, Marc, Cerf, Marianne and Grin, John, 2012b. Stimulating transitions towards sustainable farming systems. In Darnhofer, Ika, Gibbon, David and Dedieu, Benoit (eds.). Farming Systems Research into the 21st century: The new dynamic. Dordrecht: Springer.

Elzen, Boelie and Wieczorek, Anna, 2005. Transitions towards sustainability through system innovation. Technological Forecasting and Social Change, 72, 651-661.

Farla, Jacco, Markard, Jochen, Raven, Rob and Coenen, Lars, 2012. Sustainability transitions in the making: A closer look at actors, strategies and resources. Technological Forecasting and Social Change, 79, 991-998.

Eurostat, 2014. European statistics on international trade. Brussels: European Union.

Frantzeskaki, N., Henneman, P., Loorbach, D., Roorda, C., Van Steenbergen, F., Wittmayer, J., 2011. Urban Transition Management Manual. Navigator of the MUSIC Project. Rotterdam: DRIFT (Dutch Research Institute for Transitions) www.themusicproject.eu Geels, F. W. 2002. Technological transitions as evolutionary reconfiguration processes: a multi-level perspective and a case-study. Research Policy, 31, 1257-1274. 
Geels, F. W. 2004. From sectoral systems of innovation to socio-technical systems; Insight about dynamics and change form sociology and institutional theory. Research Policy, 33, $897-920$.

Groenestein, C. M. K. \& Schouten, W. G. P., 2003. Diergericht ontwerpen. Van programma van eisen naar voorbeeldontwerp voor een welzijnsvriendelijke vleesvarkenshouderij. (Animal centred designLelystad/Wageningen/Den Haag: Wageningen UR - IMAG-200307.

Groot Koerkamp, P. W. G. \& Bos, A. P. B., 2008. Designing complex and sustainable agricultural production systems; an integrated and reflexive approach for the case of table egg production in the Netherlands. NJAS - Wageningen journal of life sciences, 55, 113 138.

Hoogma, R., Kemp, R., Schot, J.W. \& Truffer, B., 2002. Experimenting for Sustainable Transport. The approach of Strategic Niche Management, London, SPON Press.

Houden van Hennen, 2004. Laying hen husbandry -- towards a happy hen life, proud farmers and a satisfied society. Wageningen / Lelystad: Wageningen UR.

Ingram, Julie, 2015. Framing niche-regime linkage as adaptation: An analysis of learning and innovation networks for sustainable agriculture across Europe. Journal of Rural Studies, $40,59-75$.

Klerkx, L., Aarts, N. \& Leeuwis, C., 2010. Adaptive management in agricultural innovation systems: The interactions between innovation networks and their environment. Agricultural Systems, 103, 390-400.

Loorbach, D. 2007. Transition Management. New mode of governance for sustainable development. Utrecht: International Books. 
Loorbach, Derk, Frantzeskaki, Niki and Lijnis Huffenreuter, Roebin, 2015. Transition Management: Taking Stock from Governance Experimentation. The Journal of Corporate Citizenship, 58. DOI: [10.9774/GLEAF.4700.2015.ju.00008]

Meynard, Jean-Marc, Dedieu, Benoit and Bos, Bram, 2012. Re-design and co-design of farming systems. An overview of methods and practices. In Darnhofer, Ika, Gibbon, David and Dedieu, Benoit (eds.). Farming Systems Research into the 21st century: The new dynamic. Dordrecht: Springer, 405-429.

Prost L., Beguin P., Cerf M., (2012). Co-design as a distributed dialogical design. In Barbier, Marc and Elzen, Boelie, 2012. System Innovations, Knowledge Regimes, and Design Practices towards Transitions for Sustainable Agriculture. Paris: INRA Editions. http://www4.inra.fr/sad_eng/Publications2/Free-e-books/System-Innovations-forSustainable-Agriculture

Rittel, H. \& Webber, M., 1973. Dilemmas in a General Theory of Planning. Amsterdam: Elsevier Scientific Publishing Company, Inc.

Roep, D., Van der Ploeg, J. D. \& Wiskerke, J. S. C. H., 2003. Managing technicalinstitutional design processes: some strategic lessons from environmental co-operatives in the Netherlands. NJAS - Wageningen journal of life sciences, 51, 195-217.

Rotmans, J., Kemp, R., Van Asselt, M., Geels, F., Verbong, G. \& Molendijk, K. 2000. Transities en Transitiemanagement. De casus van een emissiearme energievoorziening (Transitions and Transition Management. The case of a low emission energy provision). Final report of a study 'Transitions and Transition management' as input for the fourth National Environmental Policy Plan. Maastricht: ICIS \& Merit.

Schot, Johan and Geels, Frank W., 2008. Strategic niche management and sustainable innovation journeys: theory, findings, research agenda, and policy. Technology Analysis \& Strategic Management, 20 (5), 537-554. 
Schuitmaker, Tjerk Jan, 2012. Identifying and unraveling persistent problems. Technological Forecasting and Social Change, 79, 1021-1031.

Sengers, Frans, Wieczorek, Anna J. and Raven, Rob, 2016. Experimenting for sustainability transitions: A systematic literature review. Technological Forecasting and Social Change, this volume.

Siers, F. J., 2004. Methodisch ontwerpen volgens H.H. van den Kroonenberg (Structured Design according H.H. van den Kroonenberg). Amsterdam: Wolters-Noordhoff.

Slingerland, M. and Rabbinge, R. 2009. Introduction. In: Poppe, K. J., Termeer, C. J. A. M. \& Slingerland, M., (eds.) Transitions towards sustainable agriculture and food chains in peri-urban areas. Wageningen: Wageningen Academic Publishers.

Smith, A., 2007. Translating Sustainabilities between Green Niches and Socio-Technical Regimes. Technology Analysis and Strategic Management, 19, 427-450.

Smith, Adrian and Raven, Rob, 2012. What is protective space? Reconsidering niches in transitions to sustainability. Research Policy, 41, 1025-1036.

Spoelstra, S. F., Groot Koerkamp, P. W. G., Bos, A. P., Elzen, B. \& Leenstra, F., 2013. Innovation for sustainable egg production: realigning production with societal demands in The Netherlands. World's Poultry Science Journal, 69, 279-298.

UDV 2013. 4e Voortgangsrapportage Uitvoeringsagenda Duurzame Veehouderij (4 ${ }^{\text {th }}$ Progress report 'Action Agenda for Sustainable Animal Production). The Hague: Uitvoeringsagenda Duurzame Veehouderij (UDV). The fifteen long term sustainability ambitions can be found at the following website (in Dutch): http://www.uitvoeringsagendaduurzameveehouderij.nl/integraal-duurzame-veehouderij/15ambities/

Van den Kroonenberg, H. H. \& Siers, F. J. 1998. Methodisch Ontwerpen (Structured Design). Groningen: Noordhoff Uitgevers B.V. 
Van de Poel, I., 2000. On the role of outsiders in technical development. Technology Analysis \& Strategic Management, 12 (3), 383-397.

Van Mierlo, B.C., Janssen, A., Leenstra, F. \& Van Weeghel, E., 2013. Encouraging system learning in two poultry subsectors. Agricultural Systems, 115, 29-40.

Verburg, G. 2008. Toekomstvisie op de veehouderij. Brief aan de Tweede Kamer d.d. 16-012008 (Vision of the Future for Animal Production. Letter to Parliament). The Hague: LNV Ministery.

Voß, J.-P., Dierk Bauknecht and René Kemp (eds.), 2006. Reflexive Governance for Sustainable development. Cheltenham: Edward Elgar.

Weaver, P., Jansen, L., Van Grootveld, G., Van Spiegel, E. \& Vergragt, P., 2000. Sustainable technology development. Sheffield: Greenleaf Publishing.

Wijffels, H.H.F. 2001. Toekomst voor de veehouderij: Agenda voor een herontwerp van de sector. Denkgroep onder leiding van H.H.F. Wijffels. (Future for livestock production: Agenda for a redesign of the sector. Think tank presided by H.H.F. Wijffels) The Hague: LNV Ministry.

Zwartkruis, J. V., 2013. Framing in innovation. Towards sustainable agro-food systems. PhD, Utrecht University. 